\title{
Facilitation of the Estuary/Ocean Subgroup for Federal Research, Monitoring, and Evaluation, Fiscal Year 2010 Annual Report
}

\author{
Final Report
}

GE Johnson

October 2010

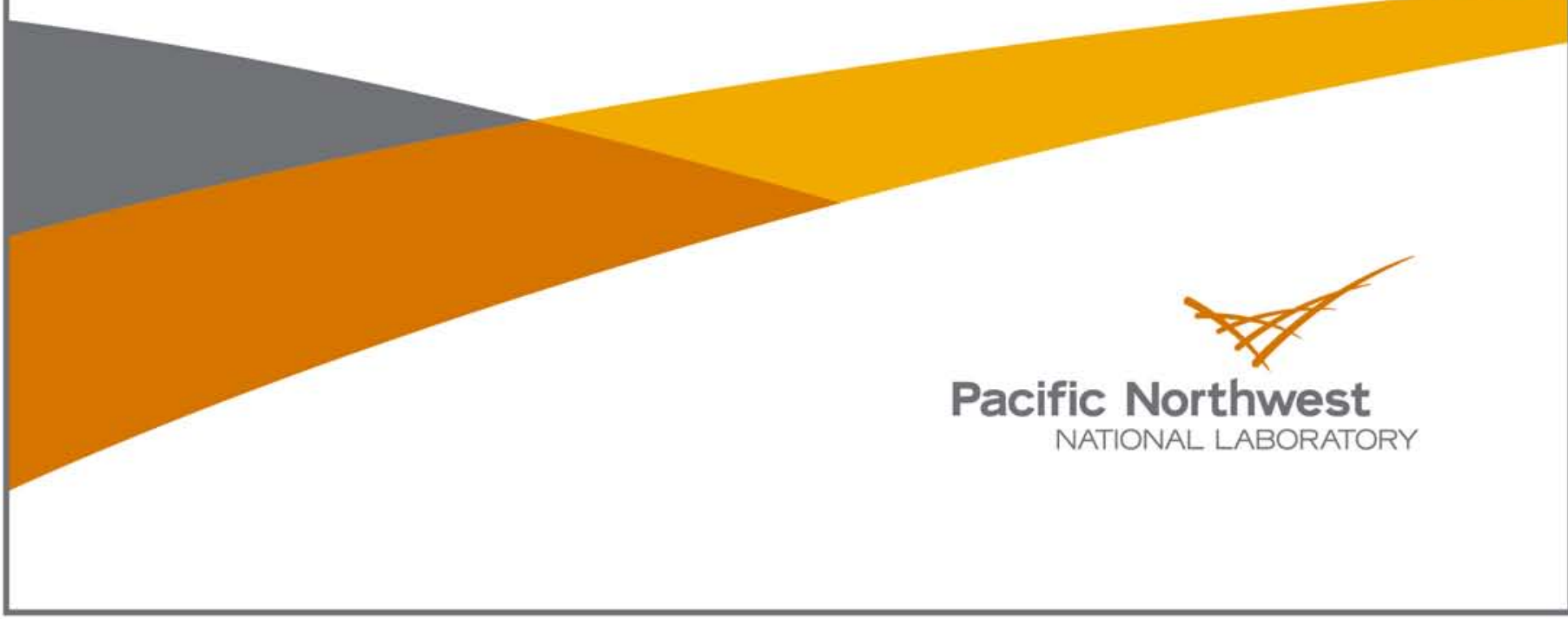




\title{
DISCLAIMER
}

This report was prepared as an account of work sponsored by an agency of the United States Government. Neither the United States Government nor any agency thereof, nor Battelle Memorial Institute, nor any of their employees, makes any warranty, express or implied, or assumes any legal liability or responsibility for the accuracy, completeness, or usefulness of any information, apparatus, product, or process disclosed, or represents that its use would not infringe privately owned rights. Reference herein to any specific commercial product, process, or service by trade name, trademark, manufacturer, or otherwise does not necessarily constitute or imply its endorsement, recommendation, or favoring by the United States Government or any agency thereof, or Battelle Memorial Institute. The views and opinions of authors expressed herein do not necessarily state or reflect those of the United States Government or any agency thereof.

\author{
PACIFIC NORTHWEST NATIONAL LABORATORY \\ operated by \\ BATTELLE \\ for the \\ UNITED STATES DEPARTMENT OF ENERGY \\ under Contract DE-AC05-76RL01830
}

Printed in the United States of America

Available to DOE and DOE contractors from the

Office of Scientific and Technical Information,

P.O. Box 62, Oak Ridge, TN 37831-0062;

ph: (865) 576-8401

fax: $(865) 576-5728$

email: reports@adonis.osti.gov

\footnotetext{
Available to the public from the National Technical Information Service, U.S. Department of Commerce, 5285 Port Royal Rd., Springfield, VA 22161 ph: (800) 553-6847 fax: $(703) 605-6900$

email: orders@ntis.fedworld.gov

online ordering: http://www.ntis.gov/ordering.htm
}

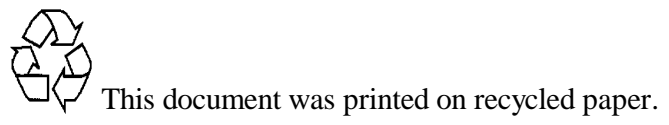




\section{Facilitation of the Estuary/Ocean Subgroup for Federal Research, Monitoring, and Evaluation, Fiscal Year 2010 Annual Report}

Final Report

GE Johnson

October 2010

Prepared for the Bonneville Power Administration under an Agreement with the U.S. Department of Energy Contract DE-AC05-76RLO1830

Pacific Northwest National Laboratory

Richland, Washington 99352 



\section{Preface}

The Estuary/Ocean Subgroup (EOS) is part of the research, monitoring, and evaluation (RME) effort that the Action Agencies (Bonneville Power Administration, U.S. Army Corps of Engineers, U.S. Bureau of Reclamation) developed in response to obligations arising from the Endangered Species Act as applied to operation of the Federal Columbia River Power System (FCRPS). The goal of the EOS project is to facilitate activities of the estuary/ocean RME subgroup as it coordinates design and implementation of federal RME in the lower Columbia River and estuary. The EOS is one of multiple work groups in the federal research, monitoring, and evaluation (RME) effort developed in response to responsibilities arising from the Endangered Species Act as a result of operation of the FCRPS. The EOS is tasked by National Oceanic and Atmospheric Administration (NOAA) Fisheries and the Action Agencies to design and coordinate implementation of the federal RME plan for the lower Columbia River and estuary, including the plume. Initiated in 2002, the EOS is composed of members from:

- Bonneville Power Administration (BPA)

- National Oceanic and Atmospheric Administration National Marine Fisheries Service (NOAA Fisheries)

- Pacific Northwest National Laboratory’s (PNNL’s) Marine Sciences Laboratory

- U.S. Army Corps of Engineers (USACE)

- other agencies as necessary.

The BPA contracted with PNNL to coordinate and facilitate the EOS (Contract No. 26934, release 26). This annual report is a fiscal year 2010 deliverable for the project titled Facilitation of the Estuary/Ocean Subgroup (BPA Project No. 2002-077-00 and PNNL Project No. 57891). Tracey Yerxa was BPA's contracting officer's technical representative for this project. For more information about the Estuary/Ocean Subgroup, please contact Gary Johnson (503-417-7567). 



\section{Acknowledgments}

Important contributions to the EOS during fiscal year 2010 were made by Blaine Ebberts (Portland District, USACE); Jim Geiselman, Russell Scranton, and Tracey Yerxa (BPA); and Catherine Corbett (Estuary Partnership). Assistance from the following PNNL staff is much appreciated: Heida Diefenderfer, Susan Ennor, Erin Nave, Mike Parker, Jan Slater, Jennifer Smith, and Ron Thom. 



\section{Acronyms and Abbreviations}

$\begin{array}{ll}\text { AER } & \text { action effectiveness research } \\ \text { BiOp } & \text { Biological Opinion } \\ \text { BPA } & \text { Bonneville Power Administration } \\ \text { CRE } & \text { Columbia River estuary } \\ \text { CREC } & \text { Columbia River Estuary Conference } \\ \text { CREDDP } & \text { Columbia River Estuary Data Development Program } \\ \text { CREST } & \text { Columbia River Estuary Study Taskforce } \\ \text { EOS } & \text { Estuary/Ocean Subgroup } \\ \text { EP } & \text { Estuary Partnership } \\ \text { FCRPS } & \text { Federal Columbia River Power System } \\ \text { FY } & \text { fiscal year } \\ \text { ISRP } & \text { Independent Scientific Review Panel } \\ \text { NMFS } & \text { National Marine Fisheries Service } \\ \text { NOAA } & \text { National Oceanic and Atmospheric Administration } \\ \text { NPCC } & \text { Northwest Power and Conservation Council } \\ \text { PNAMP } & \text { Pacific Northwest Aquatic Monitoring Partnership } \\ \text { PNNL } & \text { Pacific Northwest National Laboratory } \\ \text { RME } & \text { research, monitoring, and evaluation } \\ \text { RPA } & \text { Reasonable and Prudent Alternative } \\ \text { STM } & \text { standards and trends monitoring } \\ \text { USACE } & \text { U.S. Army Corps of Engineers } \\ \text { WE } & \text { work element (Pisces) } \\ \end{array}$




\section{Contents}

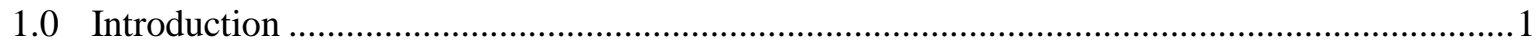

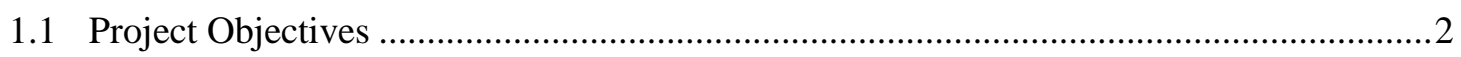

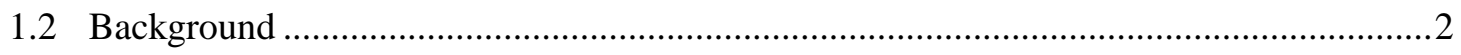

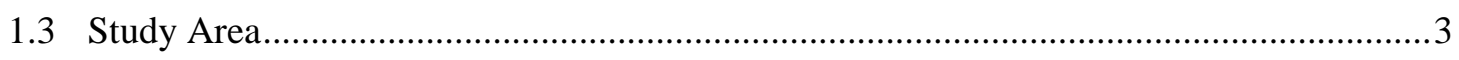

1.4 Report Contents and Organization ......................................................................

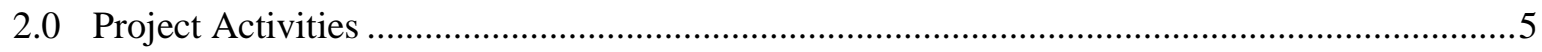

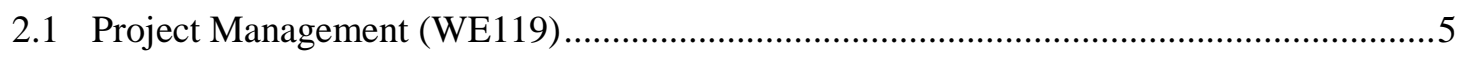

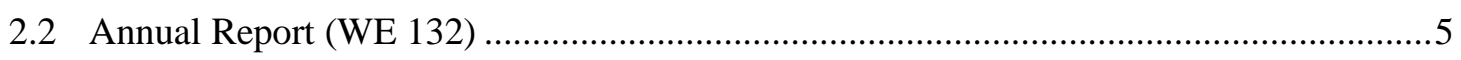

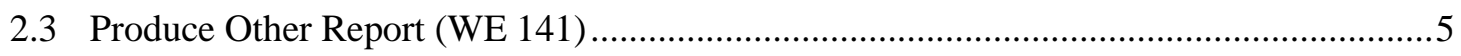

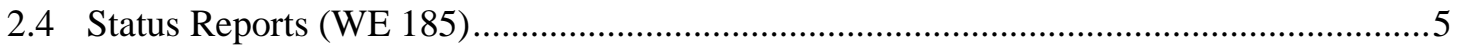

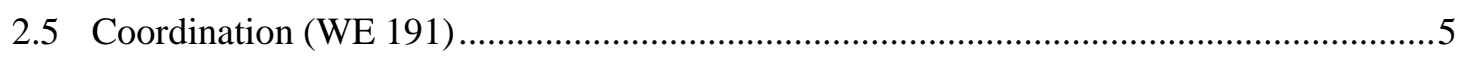

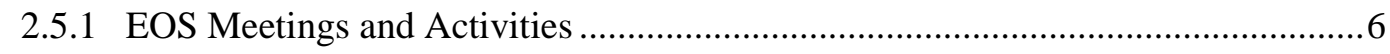

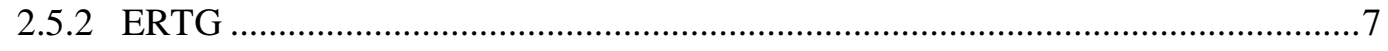

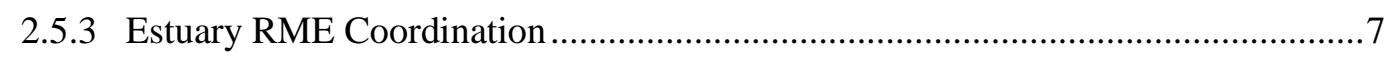

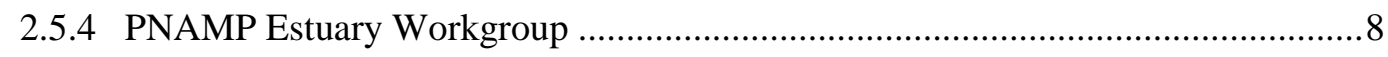

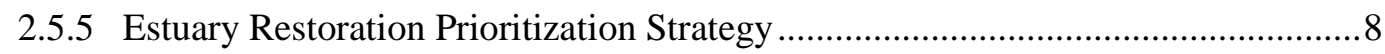

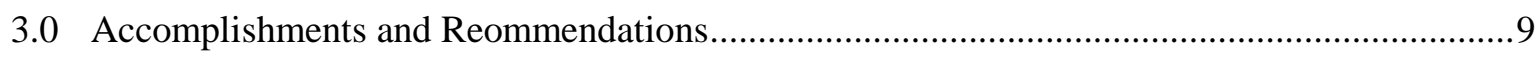

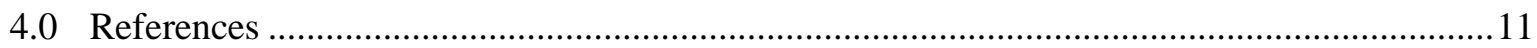

Appendix A: Summary of Research, Monitoring, and Evaluation for the Federal Columbia River

Estuary Habitat Restoration Program ................................................................................. 1

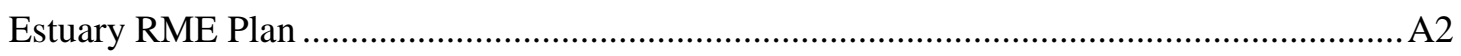

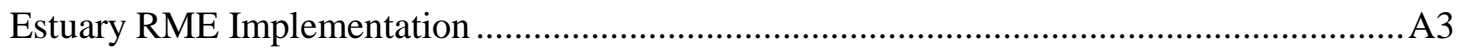

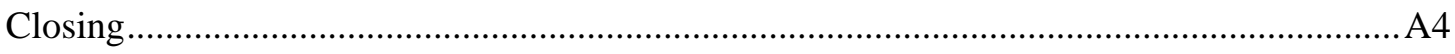

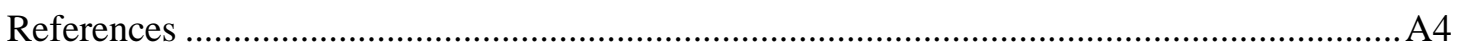

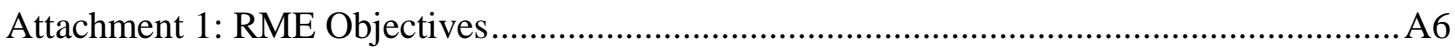

Attachment 2: Columbia River Estuary Conceptual Ecosystem Model................................A8

Attachment 3: Estuary RME.........................................................................................

Appendix B: ERTG Template for LCRE Habitat Restoration Project Summary .......................... B1

Attachment 1: Actions and Subactions from the Estuary Module That Are Applicable to the

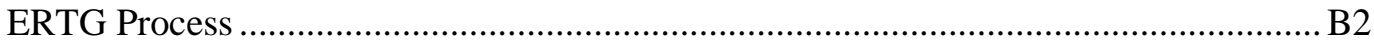

Attachment 2: ERTG Scoring Criteria (DRAFT) ............................................................ B3 


\section{Figure}

Figure 1. The Location of the Columbia River Estuary...................................

\section{Table}

Table 1. Summary of Coverage for Estuary/Ocean RME - RPA Actions 58-61.........................6 



\subsection{Introduction}

This document is the annual report for fiscal year 2010 (FY10) for the project called Facilitation of the Estuary/Ocean Subgroup (EOS). The EOS is part of the research, monitoring, and evaluation (RME) effort developed by the Action Agencies (Bonneville Power Administration [BPA], U.S. Army Corps of Engineers [Corps or USACE], and U.S. Bureau of Reclamation) in response to obligations arising from the Endangered Species Act as a result of operation of the Federal Columbia River Power System (FCRPS). For the purposes of this report, the Columbia River estuary includes main stem waters from Bonneville Dam down through the lower river and estuary into the river's plume in the ocean (Figure 1).

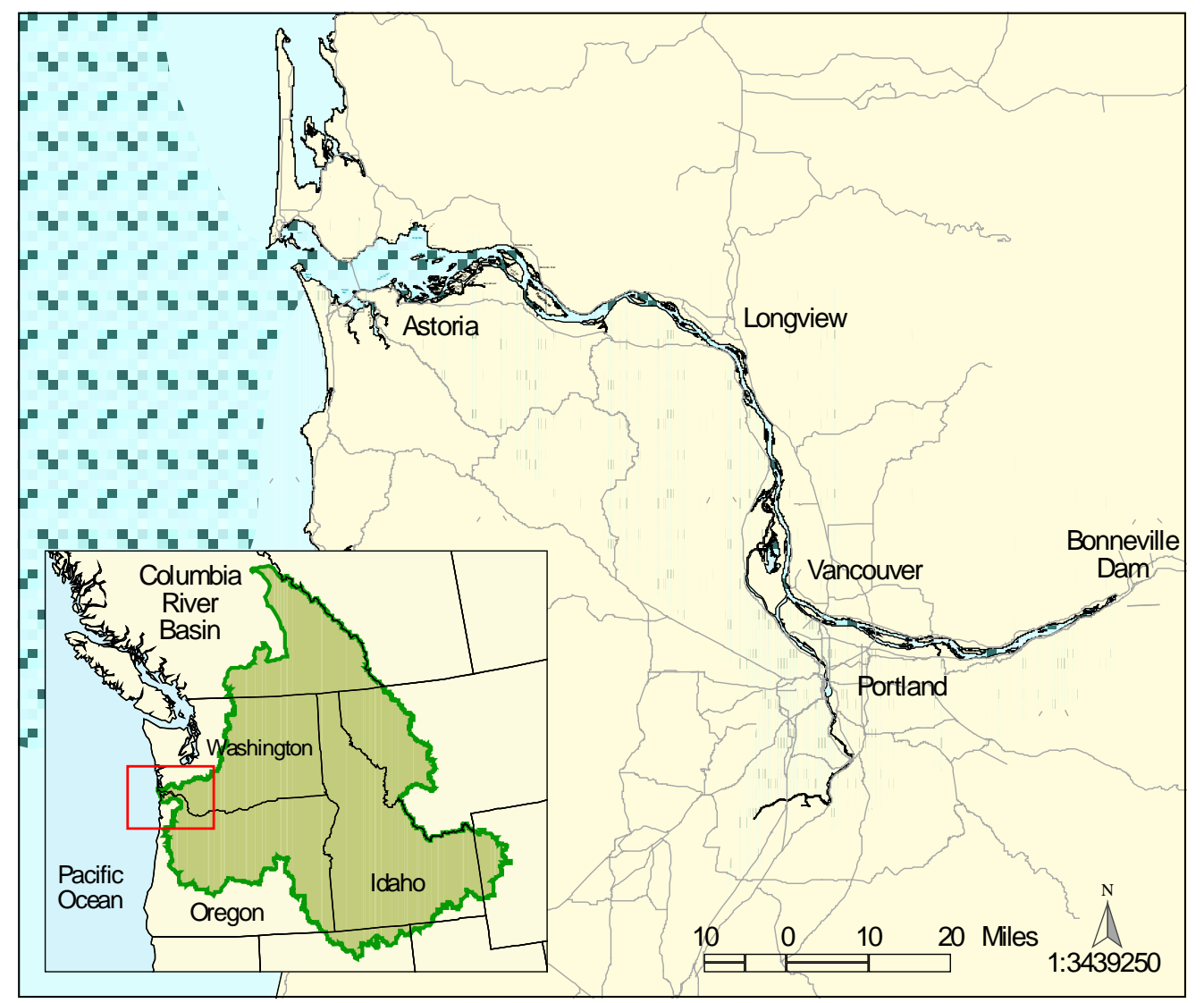

Figure 1. The Location of the Columbia River Estuary. The estuary includes the main stem, tidally influenced waters from Bonneville Dam down through the lower river and estuary into the river's plume in the ocean.

The goal of the EOS project is to facilitate EOS meetings and work products as the subgroup coordinates implementation of the Estuary RME Program with the Pacific Northwest Aquatic Monitoring Partnership (PNAMP), the Northwest Power and Conservation Council's (NPCC's) Fish and Wildlife Program, federal RME parties, and other federal and non-federal entities conducting RME in the estuary. During 2002 through 2008, the EOS worked to design the federal RME program for the estuary/ocean (Johnson et al. 2008). During 2009 to the present day, EOS activities have involved RME implementation. 


\subsection{Project Objectives}

The EOS project had the following objectives for FY10, designated by work element (WE) codes from BPA's Pisces project tracking system as of October 1, 2009:

- Manage and Administer Projects (WE 119). Manage and administer the project according to BPA’s “Work Element/Milestone” based project management and reporting system (Pisces).

- Produce Annual Report (WE 132). Produce an annual report of project activities, including under separate cover a pilot synthesis report of estuary/ocean RME as part of adaptive management at the program level.

- $\quad$ Produce Other Report (WE 141). Produce an initial version of the estuary/ocean RME synthesis report as part of adaptive management at the program level.

- Produce Status Report (WE 185). Produce quarterly status reports and upload them to Pisces.

- Watershed Coordination (WE 191). Much of the scope of work for Project No. 2002-077-00 is coordination of RME activities in the lower Columbia River, estuary, and ocean, as follows:

a) Estuary/Ocean Subgroup for Federal RME - Continue to facilitate the EOS in its mission to implement the Estuary RME Program.

b) Expert Regional Technical Group (ERTG) - Aid the Action Agencies as they continue the ERTG's work to assess survival benefits to juvenile salmon from habitat restoration in the lower Columbia River and estuary.

c) Estuary RME Coordination - Work with the Action Agencies, the Estuary Partnership, and others to convene annual estuary RME meetings of researchers and managers to present new data, exchange information, evaluate the conduct of the estuary RME program.

d) PNAMP Integrated Status and Trends Monitoring - Participate in workgroup meetings and assist in the development of coordinated estuary planning and monitoring approaches within PNAMP.

e) Steering Committee for Estuary Restoration Strategy - Attend and contribute to meetings of a new Action Agency work group intended to develop a new strategy for restoration project prioritization and selection.

\subsection{Background}

The function of the Columbia River estuary ${ }^{1}$ in the life history of threatened and endangered salmonids is more than simply serving as a corridor for passage between the tributaries and the Pacific Ocean. The estuary provides habitat for multiple life-history stages of salmon and steelhead, ranging from the rearing and feeding of fry, fingerlings, and smolts to the passage upstream of adults (Bottom et al. 2005). Use of estuary habitats by juvenile salmonids varies by species and life -history stage

\footnotetext{
${ }^{1}$ The Columbia River estuary is defined as the tidally influenced portion of the river from Bonneville Dam to the plume. This is consistent with Bottom et al. (2005) and the Lower Columbia River Estuary Program (1999). Lower Columbia River tributaries are not part of the estuary RME study area.
} 
(Rich 1920). Generally, the closer the natal stream is to the estuary and the smaller the juvenile migrant, the more likely it is that juveniles will use estuarine habitats as feeding, rearing, and refuge areas, i.e., as more than just a migration corridor (Dawley et al. 1986). Information about salmon biology and ecology in the Columbia River estuary can be found in reports by Bottom et al. (1984, 2005); Dawley et al. (1985a, b, 1986); Kirn et al. (1986); Ledgerwood et al. (1991); McCabe et al. (1983, 1986); McConnell et al. (1983); and Reimers and Loeffel (1967).

In recognition of the estuary's importance to salmon population viability, the 2008 Biological Opinion (BiOp) on operation of the FCRPS called for the restoration of estuarine habitat as a pivotal action to avoid jeopardizing the continued existence of listed salmonid populations (NOAA Fisheries 2008), as well as comprehensive research, monitoring, and evaluation for listed salmon. As a result of the $2000 \mathrm{BiOp}$ on FCRPS operations, the Action Agencies and National Oceanic and Atmospheric Administration (NOAA) Fisheries established a process to develop a basin-wide plan to guide RME efforts in the tributaries, hydrosystem, and estuary/ocean. The process involves a Policy Oversight Group and six technical subgroups: Status Monitoring, Effectiveness Research, Hydrosystem, Hatchery/Harvest, Data Management, and Estuary/Ocean. In FY10, federal RME efforts involved implementing the RME provisions defined in the $2008 \mathrm{BiOp}$.

Overall in FY10, much of the work on the EOS project concerned the ERTG for federal habitat restoration efforts in the estuary. The EOS project also worked a fair amount of time on the RPA coverage assessment initiated in FY09. The other coordination activities listed in the previous section were addressed to a lesser degree than the two main work topics. Activities and accomplishments for the EOS project during FY10 are documented in this annual report. Previous annual reports were submitted for FY05, FY06, FY07, FY08, and FY09 (Johnson 2005; Johnson 2006; Johnson and Diefenderfer 2007; Johnson and Diefenderfer 2008; and Johnson 2009, respectively).

\subsection{Study Area}

A number of publications provide descriptive information about the Columbia River estuary:

- the Salmon at River's End report by Bottom et al. (2005)

- Fresh et al.’s (2005) Role of the Estuary in the Recovery of Columbia River Basin Salmon and Steelhead

- USACE’s the Biological Assessment for the Columbia River Channel Improvements Project 2001

- the RPA Action 158 action plan by Berquam et al. (2003) and the RPA Action 159 habitat restoration report by Johnson et al. (2003)

- the NPCC’s sub-basin plan for the estuary (Lower Columbia River Estuary Partnership and Lower Columbia Fish Recovery Board 2004a, 2004b).

Important earlier compendiums include the following:

- The Columbia River Estuary and Adjacent Ocean Waters by Pruter and Alverson (1972)

- "Columbia River Estuary” in Changes in Fluxes in Estuaries: Implications from Science to Management by Dyer and Orth (1994) 
- Columbia River: Estuarine System by Small (1990), which contains reviews of earlier work supported by the Columbia River Estuary Data Development Program (CREDDP) on physical and biological processes (CREDDP 1984a, 1984b).

\subsection{Report Contents and Organization}

The ensuing sections of this FY10 annual report for the EOS project describe project activities, summarize accomplishments, and provide recommendations for FY10. The sections on activities and accomplishments are organized by the work elements listed previously under project objectives (Section 1.1). Appendix A contains a summary of research, monitoring, and evaluation in the lower Columbia River and estuary. Appendix B contains the ERTG's template for restoration project summaries. 


\subsection{Project Activities}

EOS project activities during FY10 included project management, publishing the annual report and status reports, and coordination efforts; as described in the following sections for each work element (WE).

\subsection{Project Management (WE119)}

The project was managed according to procedures and principles set forth in PNNL's Standard Business and Management System. As requested by BPA, PNNL developed and submitted the FY11 scope of work and budget for Project 2002-077-00 to BPA via Pisces in July 2010.

\subsection{Annual Report (WE 132)}

This document fulfills the annual report objective.

\subsection{Produce Other Report (WE 141)}

The EOS for federal RME proposed the idea for a synthesis report about RME in the lower Columbia River and estuary (LCRE) in the estuary/ocean RME plan (Johnson et al. 2008). In FY09, the EOS assessed the coverage of estuary/ocean Reasonable and Prudent Alternatives (RPAs) in the 2008 BiOp (NMFS 2008). One of the main findings was an overarching need for synthesis of the collective information about many RPAs. These "roll-ups" will be relevant to BiOp reporting requirements.

The BPA, however, decided to not use the EOS project to pursue the objective to produce an initial version of the estuary/ocean RME synthesis report as part of adaptive management at the program level. Instead, the BPA intends to contract with other entities (to be determined). Project resources allocated for WE 141 were transferred to WE 191.

\subsection{Status Reports (WE 185)}

Status reports on Project 2002-077-00 were submitted quarterly by PNNL to BPA during FY10. The status reports contained information about whether progress was satisfactory by milestone for each work element.

\subsection{Coordination (WE 191)}

The bulk of the work on the EOS project falls under the coordination work element. The material that follows is organized by the topics listed under the coordination objective in Section 1.1. 


\subsubsection{EOS Meetings and Activities}

During July 2010, a summary of estuary/ocean RME efforts was prepared (Appendix A). The BPA used the summary to further the Independent Scientific Review Panel's (ISRP's) understanding of the federal estuary/ocean RME effort.

During FY10, the EOS met formally one time. On February 22, 2010, an EOS meeting was held at PNNL's Portland office and attended by Geiselman (BPA; phone), Johnson (PNNL), O'Toole (NPCC), Ruff (NPCC), and Yerxa (BPA; phone). The meeting purpose was to revisit the 2009 assessment of coverage of the RPAs for estuary RME (58-61) by the current suite of RME projects. We attempted to ensure the gap assessment was up to date given developments in the past year, such as the Washington Memorandum of Understanding and an accelerated Estuary Restoration Program. Coverage of the hatchery, tributary, harvest, and hydrosystem RPAs has already undergone a similar review. The RPA gap assessments will be useful for the Action Agencies' 2010 Implementation Plan and the RME Categorical Review process in the Council's Fish and Wildlife Program. The discussion focused on RPA 60, with mention of parts of the other RPAs. Proposed edits are contained in Attachment 3, RPA Coverage Report, drafted as an outcome of the 2/22/10 meeting.

The BPA organized and implemented a meeting with the ISRP for the Columbia Basin Fish and Wildlife Program. The meeting purpose was to present information to further the ISRP's understanding of the federal RME effort, with special note of significant gaps in coverage of the 2008 FCRPS BiOp. The meeting, which was held on April 29, 2010, at the NPCC offices in Portland, Oregon, was timely because the ISRP will be formally reviewing RME projects in the Council's categorical review process. The EOS coverage assessment of estuary/ocean RME for the 2008 FCRPS BiOp was reported.

The EOS's updated coverage assessment was included in the RME Recommendations Report (Action Agencies 2010). The summary table, excerpted and edited from the report, follows (Table 1).

Table 1. Summary of Coverage for Estuary/Ocean RME - RPA Actions 58-61. Red implies a gap; green implies no gap; clear implies the RPA subaction was assessed by the Hydro/Predation RME Subgroup; the letters link to notes below the table. Excerpted from Action Agencies (2010).

\begin{tabular}{|c|c|c|c|c|c|c|c|c|c|c|c|c|c|c|c|c|}
\hline RPA & 58.1 & 58.2 & 58.3 & 58.4 & 59.1 & 59.2 & 59.3 & 59.4 & 59.5 & 60.1 & 60.2 & 60.3 & 61.1 & 61.2 & 61.3 & 61.4 \\
\hline Gap & A & & B & C & D & $\mathbf{E}$ & & $\mathbf{F}$ & G & $\mathbf{L}$ & $\mathbf{K}$ & $\mathbf{M}$ & $\mathbf{H}$ & & I & \\
\hline \multicolumn{17}{|c|}{${ }^{\mathrm{A}}$ No gap for survival, but there is one for fitness. } \\
\hline \multicolumn{17}{|c|}{$\begin{array}{l}{ }^{\mathrm{B}} \text { Gap in that more (TBD) representative sample sites are needed, in addition to an estuary-wide roll-up. } \\
\text { The Corps, however, respectfully disagrees because this subaction is being addressed with intensive } \\
\text { data from action effectiveness research on the realized benefits from habitat restoration. }\end{array}$} \\
\hline \multicolumn{17}{|c|}{${ }^{\mathrm{C}}$ Defer to Hydro/Predation Workgroup. } \\
\hline \multicolumn{17}{|c|}{${ }^{\mathrm{D}}$ Gap until the bathymetry and topographic mapping are completed. This is a high priority. } \\
\hline \multicolumn{17}{|c|}{$\begin{array}{l}{ }^{\mathrm{E}} \text { Gap in that estuarine ecosystem classification and associated maps will be for only two of eight reaches. } \\
\text { This is a high priority. }\end{array}$} \\
\hline \multicolumn{17}{|c|}{ Cont'd } \\
\hline
\end{tabular}


${ }^{\mathrm{F}}$ Gap in knowledge of the relative importance of various habitat types to juvenile salmon. The Corps respectfully disagrees because, in its opinion, the existing research meets the intent/need of this subaction.

${ }^{\mathrm{G}}$ Gap in coverage estuary-wide.

${ }^{\mathrm{H}}$ Gap because a roll-up has not been started; the schedule calls for it to commence in FY2010. The synthesis/roll-up is a high priority.

${ }^{\mathrm{I}}$ Ibid.

${ }^{\mathrm{K}}$ Currently this RPA is covered with the existing level of monitoring. As additional types and intensities of actions are planned and implemented, there will be a need for additional action effectiveness monitoring and research.

${ }^{\mathrm{L}}$ F\&WP Project 2003-011-00 needs to complete the reference site integration and provide a dissemination mechanism. The Action Agencies will assess whether the existing suite of reference sites is sufficient given the increase in the number of habitat restoration projects and the need for action effectiveness research for a subset of them.

${ }^{\mathrm{M}}$ Make sure the deliverables from this project are carried forward after the projects ends in spring 2011. Periodic cumulative effects assessments are needed to understand whether the restoration actions are having the desired effects.

\subsubsection{Expert Regional Technical Group}

The ERTG for Survival Benefits of Habitat Restoration was established by the Action Agencies. During FY10, eight public ERTG meetings were held to assess the survival benefits from habitat restoration: October 21, 2009 and February 9, February 16, March 23, April 7, May 24, June 3, and July 21, 2010. Meetings notes can be obtained by contacting G. Johnson (503 417-7567).

During FY10, the ERTG drafted a template for restoration sponsors to use to provide summary information about proposed projects. The project template is contained in Appendix B of this report.

The ERTG also developed scoring criteria to use in the process to assign survival benefit units. The scoring criteria also provide useful guidance to project sponsors. Because of this, they were included as an attachment to the project template (in Appendix B). The ERTG scored 14 projects.

The draft process to assign survival units uses scores for certainty of success, potential benefit to habitat access/opportunity, and potential benefit to habitat capacity/quality, along with data on a given project's restoration goals (acres or miles), and information from the Estuary Module to calculate an assigned survival benefit unit separately for ocean-type and stream-type life histories.

\subsubsection{Estuary RME Coordination}

EOS members participated in a meeting convened by the Estuary Partnership (EP) in spring 2010 to coordinate research activities in the LCRE, especially those of three projects: Ecosystem Monitoring (EP), Salmon Ecology and Restoration in Tidal Freshwater (PNNL/Oregon Department of Fish and Wildlife, ODFW), and Tidal Fluvial Research (National marine Fisheries Service, NMFS). The projects 
have distinctly different goals and objectives. The researchers agreed to routinely communicate sampling locations and schedules.

\subsubsection{PNAMP Estuary Workgroup}

The PNAMP Estuary Workgroup did not meet during FY10.

\subsubsection{Estuary Restoration Prioritization Strategy}

A workshop was conducted in the first quarter of FY10 for BPA's restoration prioritization strategy project led by P.C. Trask and Associates. Johnson participated in this workshop and, when appropriate, described pertinent estuary RME activities. For example, research to sample juvenile salmon in the LCRE and estimate genetic stock identification is a key source of data upon which the restoration prioritization strategy will be based. 


\subsection{Accomplishments and Recommendations}

During FY10, EOS accomplishments for BPA Project 2002-077-00 were as follows:

- Continued to facilitate EOS activities as the subgroup worked to implement the federal Estuary Research, Monitoring, and Evaluation Program and provide input to the broader federal RME effort, including a summary of estuary/ocean RME efforts.

- Continued to facilitate and document activities of the ERTG and its Steering Committee.

- Helped plan the NPCC’s Science-to-Policy Exchange for the Estuary. This event was held September 9-10, 2009 in Astoria, Oregon.

- Finalized the estuary/ocean RME gap analysis for federal RME coverage of the 2008 FCRPS BiOp and presented this material at a meeting with the ISRP.

- Listed significant contributions from estuary/ocean RME during 2009 for the Action Agencies’ 2009 Annual Progress Report.

Project work in FY11 will include facilitation of the EOS, assisting the expert regional technical group on survival benefits of habitat restoration, and helping with strategic planning for restoration. In addition to the usual project management, annual report, and status report, the following activities and deliverables, are planned for FY11 under Project 2002-077-00.

- Estuary/Ocean Subgroup for Federal RME - Continue to facilitate the EOS in its mission to implement the Estuary RME Program.

- RPA 37 Expert Regional Technical Group - Aid the Action Agencies as they continue the ERTG's work to assess survival benefits to juvenile salmon from habitat restoration in the LCRE. Convene and coordinate with subcontractors who will be members of the ERTG.

- PNAMP Integrated Status and Trends Monitoring - Participate in workgroup meetings and assist in the development of coordinated estuary planning and monitoring approaches within PNAMP.

- Steering Committee for Estuary Restoration Strategy - Attend and contribute to meetings of a new Action Agency work group intended to develop a new strategy to restoration project prioritization and selection. 



\subsection{References}

Action Agencies. 2010. Recommendations for Implementing Research, Monitoring and Evaluation for the 2008 NOAA Fisheries FCRPS BiOp - Based on AA/NOAA/NPCC RM\&E Workgroup Assessments. Bonneville Power Administration, Portland, Oregon.

Berquam, TB, BD Ebberts, and J Wilcox. 2003. Action Plan to Implement the FCRPS Biological Opinion in the Columbia River Estuary. Prepared by the U.S. Army Corps of Engineers, Portland District, Portland, Oregon.

Bottom, DL, KK Jones, and JJ Herring. 1984. Fishes of the Columbia River Estuary. Columbia River Data Development Program, Columbia River Estuary Study Taskforce, Astoria, Oregon.

Bottom, DL, CA Simenstad, J Burke, AM Baptista, DA Jay, KK Jones, E Casillas, and MH Schiewe. 2005. Salmon at River's End: The Role of the Estuary in the Decline and Recovery of Columbia River Salmon. NOAA Technical Memorandum National Oceanic and Atmospheric Administration (NOAA) Fisheries-NWFSC-68, Northwest Fisheries Science Center, Seattle, Washington.

Columbia River Estuary Data Development Program (CREDDP). 1984a. Index to CREDDP Data. Compiled by HT Mercier; S. Bell, ed., Columbia River Estuary Study Taskforce, Astoria, Oregon.

Columbia River Estuary Data Development Program (CREDDP). 1984b. Abstracts of Major CREDDP Publications. Compiled by D Fox, Columbia River Estuary Study Taskforce, Astoria, Oregon.

Dawley, EM, RD Ledgerwood, and AL Jensen. 1985a. Beach and Purse Seine Sampling of Juvenile Salmonids in the Columbia River Estuary and Ocean Plume, 1977-1983; Volume I; Procedures, Sampling Effort and Catch Data. NOAA Technical Memorandum F/NWC-74:1-260, National Oceanic and Atmospheric Administration (NOAA) Fisheries, Seattle, Washington.

Dawley, EM, RD Ledgerwood, and AL Jensen. 1985b. Beach and Purse Seine Sampling of Juvenile Salmonids in the Columbia River Estuary and Ocean Plume, 1977-1983; Volume II; Data on Marked Fish Recoveries. NOAA Technical Memorandum F/NWC-75:1-397, National Oceanic and Atmospheric Administration (NOAA) Fisheries, Seattle, Washington.

Dawley, EM, RD Ledgerwood, TH Blahm, CW Sims, JT Durkin, RA Kirn, AE Rankis, GE Monan, and FJ Ossiander. 1986. Migrational Characteristics, Biological Observations, and Relative Survival of Juvenile Salmonids Entering the Columbia River Estuary, 1966-1983. Prepared by the National Oceanic and Atmospheric Administration NOAA Fisheries, Northwest Fisheries Science Center, Seattle, Washington.

Dyer, KR and RJ Orth (eds.). 1994. Changes in Fluxes in Estuaries: Implications from Science to Management. Proceedings of ECSA22/ERF Symposium, 13-18 September 1992, Institute of Marine Studies, University of Plymouth. Olsen \& Olsen, Fredensborg. 
Fresh, K, E Casillas, L Johnson, and D Bottom. 2005. Role of the Estuary in the Recovery Columbia River Basin Salmon and Steelhead: An Evaluation of Selected Factors on Salmonid Population Viability. NOAA Technical Memorandum NMFS-NWFSC-69, National Oceanic and Atmospheric Administration (NOAA) Fisheries, Northwest Fisheries Science Center, Seattle, Washington.

Johnson, G. 2005. Estuary/Ocean Research, Monitoring, and Evaluation Support Project: FY05 Annual Report. Final report by the Pacific Northwest National Laboratory, Richland, Washington, for the Bonneville Power Administration, Portland, Oregon.

Johnson, G. 2006. Facilitation of the Estuary/Ocean Subgroup for Research, Monitoring, and Evaluation, FY06 Annual Report. PNNL-16142, final report by the Pacific Northwest National Laboratory, Richland, Washington, for the Bonneville Power Administration, Portland, Oregon.

Johnson, G. 2009. Facilitation of the Estuary/Ocean Subgroup for Research, Monitoring, and Evaluation, FY06 Annual Report. PNNL-18907, final report by the Pacific Northwest National Laboratory, Richland, Washington, for the Bonneville Power Administration, Portland, Oregon.

Johnson, GE and HL Diefenderfer. 2007. Facilitation of the Estuary/Ocean Subgroup for Research, Monitoring, and Evaluation, FY07 Annual Report. PNNL-16947, final report by the Pacific Northwest National Laboratory, Richland, Washington, for the Bonneville Power Administration, Portland, Oregon.

Johnson, GE and HL Diefenderfer. 2008. Facilitation of the Estuary/Ocean Subgroup for Research, Monitoring, and Evaluation, FY08 Annual Report. PNNL-17811, final report by the Pacific Northwest National Laboratory, Richland, Washington, for the Bonneville Power Administration, Portland, Oregon.

Johnson G.E., R.M. Thom, A.H. Whiting, G.B. Sutherland, T. Berquam, B.D. Ebberts, N.M. Ricci, J.A. Southard, and J.D. Wilcox. 2003. An Ecosystem-Based Approach to Habitat Restoration Projects with Emphasis on Salmonids in the Columbia River Estuary. PNNL-14412, final report submitted to the Bonneville Power Administration, Portland, Oregon, November 2003, by Pacific Northwest National Laboratory, Richland, WA.

Johnson, GE, HL Diefenderfer, BD Ebberts, C Tortorici, T Yerxa, J Leary, and J Skalski. 2008. Research Monitoring and Evaluation for the Federal Columbia River Estuary Program. PNNL-17300, final report by the Pacific Northwest National Laboratory, Richland, Washington, for the Bonneville Power Administration, Portland, Oregon.

Kirn, RA, RD Ledgerwood, and AL Jensen. 1986. "Diet of Subyearling Chinook Salmon (Oncorhynchus tshawytscha) in the Columbia River Estuary and Changes Effected by the 1980 Eruption of Mount St. Helens.” Northwest Science 60:191-196.

Ledgerwood, RD, FP Thrower, and EM Dawley. 1991. "Diel sampling of migratory juvenile salmonids in the Columbia River estuary.” Fisheries Bulletin 89:69-78. 
Lower Columbia River Estuary Partnership and Lower Columbia Fish Recovery Board. 2004a. Lower Columbia Salmon and Steelhead Recovery and Subbasin Plan. Volume I and II. Report prepared for the Northwest Power and Conservation Council, May 28, 2004. Available at http://www.nwcouncil.org/fw/subbasinplanning/lowerColumbia/plan/.

Lower Columbia River Estuary Partnership and Lower Columbia Fish Recovery Board. 2004b. Supplement to the Main stem Lower Columbia River and Columbia River Estuary Subbasin Plan. Prepared for the Northwest Power and Conservation Council, November 22, 2004. Available at http://www.lcrep.org/pdfs

McCabe, GT Jr, WD Muir, and JT Durkin. 1983. "Interrelationships between juvenile salmonids and nonsalmonid fish in the Columbia River Estuary.” U.S. Bur. Fish. Bull. 81:815-826.

McCabe, GT Jr, RL Emmett, WD Muir, and TH Blahm. 1986. Utilization of the Columbia River Estuary by Subyearling Chinook Salmon. Northwest Science, 60(2):113-124.

McConnell, R, T Blahm, G McCabe, T Clocksin, T Coley, J Durkin, R Emmett, and W Muir. 1983. Columbia River Estuary Data Development Program Data Report: Salmonid and Non-Salmonid Fish, four volumes. Columbia River Estuary Data Development Program, managed by Columbia River Estuary Taskforce, Astoria, Oregon.

National Oceanic and Atmospheric Administration (NOAA) Fisheries. 2008. Biological OpinionConsultation on Remand for Operation of the Federal Columbia River Power System, 11 Bureau of Reclamation Projects in the Columbia Basin and ESA Section 10(a)(1)(A) Permit for Juvenile Fish Transportation Program. National Marine Fisheries Service (NOAA Fisheries) - Northwest Region. Seattle, Washington.

Pruter, AT and DL Alverson (eds.). 1972. The Columbia River Estuary and Adjacent Ocean Waters: Bioenvironmental Studies. University of Washington Press, Seattle, Washington.

Reimers, PE and RE Loeffel. 1967. "The Length of Residence of Juvenile Fall Chinook Salmon in Selected Columbia River Tributaries.” Res. Briefs, Fish Comm. Oreg. 13(1):5-19

Rich, WH. 1920. "Early history and seaward migration of Chinook salmon in the Columbia and Sacramento rivers.” U.S. Bur. Fish. Bull. 37:2-73.

Roegner, GC, HL Diefenderfer, AB Borde, RM Thom, EM Dawley, AH Whiting, SA Zimmerman, and GE Johnson. 2008. Protocols for Monitoring Habitat Restoration Projects in the Lower Columbia River and Estuary. PNNL-15793, prepared by NOAA Fisheries, Hammond, Oregon, and Pacific Northwest National Laboratory, Richland, Washington, for the U.S. Army Corps of Engineers, Portland District, Portland, Oregon.

Small, LF (ed.). 1990. “Columbia River: Estuarine System.” Progress in Oceanography 25(1-4).

U.S. Army Corps of Engineers (USACE). 2001. Biological Assessment Columbia River Channel Improvements Project. Prepared by the U.S. Army Corps of Engineers for the National Oceanic and Atmospheric Administration Fisheries and U.S. Fish and Wildlife Service, Portland, Oregon. 


\title{
Appendix A
}

\section{Summary of Research, Monitoring, and Evaluation for the Federal Columbia River Estuary Habitat Restoration Program}

\author{
July 28, 2010, G. Johnson
}

The purpose of this document is to describe the research, monitoring, and evaluation (RME) activities of the Federal Columbia River Estuary Habitat Restoration Program, hereafter called "the Estuary Program.” The intent of the RME effort is to provide data and information to evaluate progress toward meeting program goals and objectives and support decision making in the Estuary Program. The study area is the floodplain in the lower Columbia River and estuary (LCRE), from Bonneville Dam to the mouth. The primary management questions pertaining to estuary habitat restoration are as follows:

1. Are the estuary habitat actions achieving the expected biological and environmental performance?

2. Are the offsite habitat actions in the estuary improving juvenile salmonid performance and which actions are most effective at addressing the limiting factors preventing achievement of habitat, fish, or wildlife performance objectives?

3. What are the limiting factors or threats in the estuary/ocean preventing the achievement of desired habitat or fish performance objectives?

The goal of estuary RME is to provide pertinent and timely research and monitoring information to planners, implementers, and managers of the Estuary Program. To address the estuary RME goal and management questions, estuary RME has specific objectives for status and trends monitoring, action effectiveness and critical uncertainties research, implementation/compliance, and synthesis/evaluation (see Attachment 1). Estuary RME are conducted within the Estuary Program's adaptive management framework (see Figure A.1). 


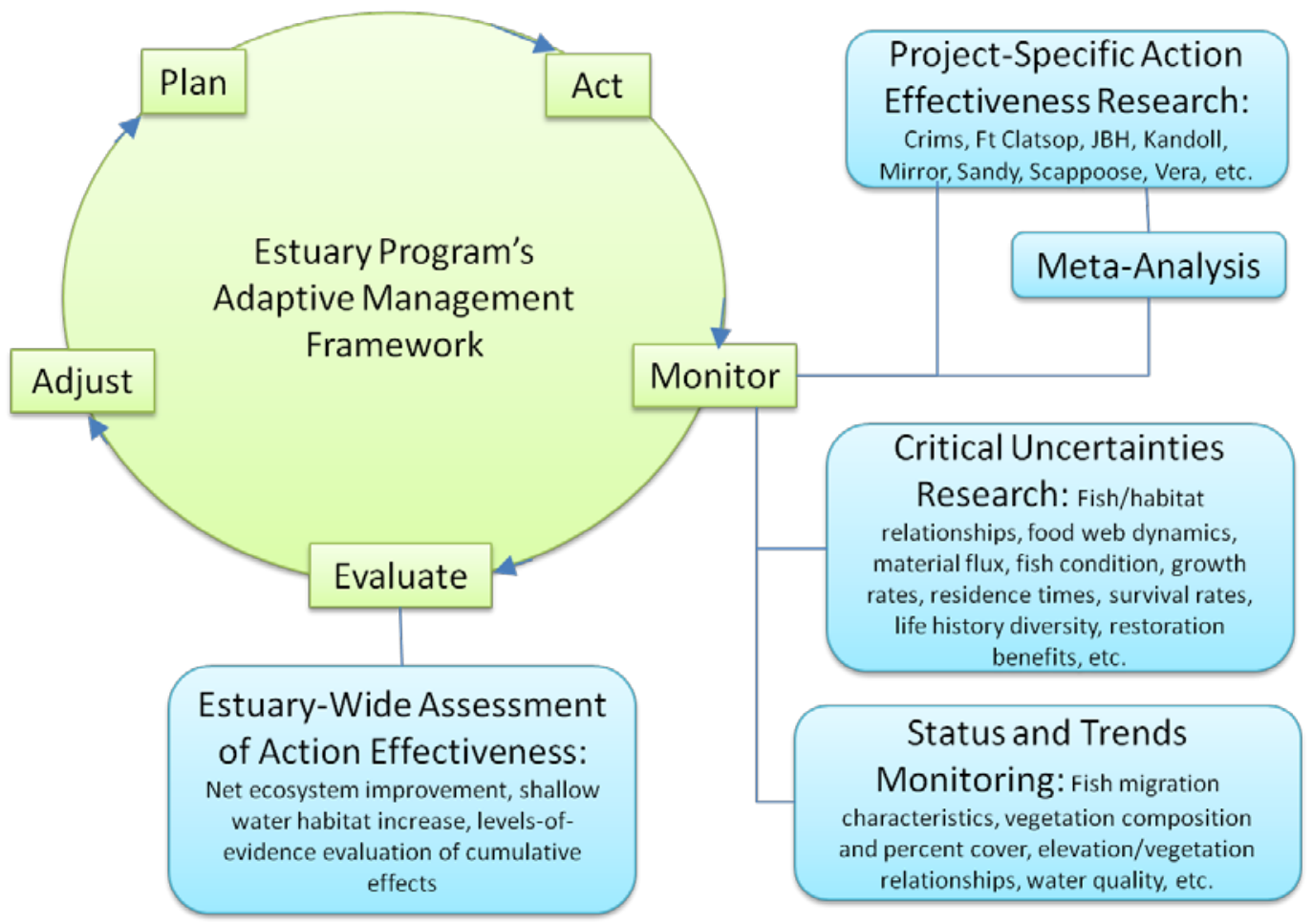

Figure A.1. The Estuary Program’s Adaptive Management Framework

\section{A.1 Estuary RME Plan}

To design and implement the estuary RME, the Action Agencies and the National Oceanic and Atmospheric Administration (NOAA) have developed a comprehensive plan (Johnson et al. 2008). Many elements of this plan were incorporated into the Federal Columbia River Power System (FCRPS) Biological Opinion (NOAA 2008; RPAs 58-61). RME includes a monitoring plan (Chapter 2) for the status and trends monitoring and action effectiveness research objectives, a research plan (Chapter 3) for the critical uncertainties research objectives, and an action plan (Chapter 4) for the implementation/compliance and synthesis and evaluation objectives. Status and trends monitoring is important because it will reveal whether LCRE ecosystem features that support salmonids are improving, staying the same, or degrading. Action effectiveness research in the LCRE is important because it will show the ecological results from the primary management action in the LCRE-habitat restoration—and provide feedback to managers for the next-generation habitat projects. Knowledge developed from status and trends monitoring and action effectiveness research, when integrated with scientific findings from critical uncertainties research, will help guide management actions on the estuary.

The monitoring plan uses a framework that provides the scientific basis for status and trends monitoring (STM) in the LCRE. The overall objective of STM is to measure monitored indicators that are ecologically significant to listed salmonids in the LCRE, while specific objectives deal with ecosystem controlling factors, structures, and salmonid performance. The Columbia River Estuary Conceptual Model forms a basis for the selection of monitored indicators for each objective (see Attachment 2). A rotational split panel sampling design is being instituted. Data-collection methods, the spatial and temporal scale of monitoring, and example protocols are provided by Johnson et al. (2008). 
The overall purpose of action effectiveness research (AER) is to use quantitative studies to demonstrate how habitat restoration actions affect factors controlling ecosystem structures and processes at site and landscape scales and, in turn, juvenile salmonid performance. This work directly addresses the first and second management questions above. The specific AER objectives address effectiveness and validation monitoring. AER is conducted whenever possible using a before-after-reference-impact design. A network of reference sites has been developed that is crucial to this effort. Collective effectiveness data are analyzed using a control chart method based on data from a suite of reference and restoration sites and a meta-analysis method. Data-collection methods for action effectiveness, as well as the spatial and temporal scale of monitoring and example protocols, are provided by Johnson et al. (2008). Roegner et al. (2009) provide effectiveness monitoring protocols.

The research plan's overall objective is to investigate critical uncertainties in the state-of-the-science in the LCRE that are pivotal to understanding fish performance. The focus is on addressing critical uncertainties underlying the management questions. Specific uncertainties pertain to the ecological importance of the LCRE to salmonids, causal mechanisms affecting survival, early life history in tidal freshwater, effects of hatchery fish on wild fish in the estuary, factors affecting wetting and drying of floodplain habitats, food web dynamics, etc. Many of the monitored indicators for research are ecosystem processes and linkages between these and ecosystem structures and salmonid performance (Attachment 2 ). Results from uncertainties research will reduce risk during management decision-making for the Estuary Program.

The action plan responds to RME needs at project and program levels. The intent is to implement estuary RME across multiple entities whose projects, programs, and processes address the estuary RME objectives (Attachment 1). Diverse groups of entities implement estuary RME.

\section{A.2 Estuary RME Implementation}

Coordination processes are well-established. Federal estuary RME are funded mostly by the Bonneville Power Administration (BPA) through its Fish and Wildlife Program and the U.S. Army Corps of Engineers (USACE) through its Anadromous Fish Evaluation Program. Both programs have welldefined program-specific coordination and review processes. On an overarching basis, the Estuary/Ocean Subgroup for federal RME coordinates overall estuary RME planning and implementation. Furthermore, the Estuary Partnership convenes an annual meeting of the Action Agencies, NOAA, Estuary Partnership, and other entities charged with research and monitoring in the estuary; the most recent meeting was in spring 2010. The Estuary Partnership also reviews estuary RME results in its Science Work Group. The Action Agencies coordinate estuary RME with other basin-wide RME groups, other federal monitoring programs, interested parties, and state and local monitoring efforts. Finally, the BPA and USACE have cross-agency coordination meetings that include estuary RME.

Data management, analysis, and dissemination are receiving attention. Data specifications for estuary RME are being developed to support a coordinated data-management system. Standardized methods for status and trends monitoring and action effectiveness research have been developed to allow comparisons through time for given monitored attributes (Johnson et al. 2008; Roegner et al. 2009). The Estuary Partnership is working to build a data center to house results from status and trends monitoring and action effectiveness research. The data center will include a central, web-accessible repository for estuary data, and a publicly accessible homepage with links to a networked system of databases. The intent is to link this system to basin-wide RME data to facilitate basin-wide evaluations. And, the Estuary 
Partnership maintains a project inventory database for restoration projects in the Estuary Program and associated action effectiveness data.

Information is reported through several avenues. A biennial estuary conference is convened to evaluate the conduct of the estuary RME effort, exchange information, and provide input to managers. This event, most recently held in May 2010, typically includes presentations of new data about action effectiveness and critical uncertainties. Planning is underway to produce a biennial, synthesis report of estuary RME activities and results. This report series would summarize data and provide adaptive management recommendations at the program level for submittal to the Action Agencies, estuary restoration project leaders, and other related entities. The Action Agencies and their partners are working to establish procedures that link decision makers and RME practitioners in a manner consistent with basin-wide adaptive management. Such a step is part of the USACE's Adaptive Management Plan for the Estuary Program.

\section{A.3 Closing}

The estuary RME effort is designed to meet the research and monitoring needs of the Estuary Program in the context of the Program's adaptive management process. The significant body of estuary RME developed over the last 30 years (Attachment 3) continues to grow and provide support to the Estuary Program. The success and usefulness of estuary RME to Estuary Program decision makers depends on dedicated, consistent conduct of RME planning, implementation, data management, reporting, synthesis, and evaluation.

National Oceanic and Atmospheric Administration (NOAA) Fisheries. 2008. Biological OpinionConsultation on Remand for Operation of the Federal Columbia River Power System, 11 Bureau of Reclamation Projects in the Columbia Basin and ESA Section 10(a)(1)(A) Permit for Juvenile Fish Transportation Program. National Marine Fisheries Service (NOAA Fisheries) - Northwest Region. Seattle, Washington.

\section{A.4 References}

Borde, AB, HL Diefenderfer, SA Zimmerman, NK Sather, and RM Thom. 2009. Lower Columbia River and Estuary Restoration Reference Site Study 2008 Report. PNWD-4133, prepared by Battelle Pacific Northwest Division, Richland, Washington.

Bottom, DL, CA Simenstad, J Burke, AM Baptista, DA Jay, KK Jones, E Casillas, and M Schiewe. 2005. Salmon at River's End: the Role of the Estuary in the Decline and Recovery of Columbia River Salmon. NOAA Technical Memorandum NMFS-NWFSC-68, National Oceanic and Atmospheric Administration (NOAA) Fisheries, Northwest Fisheries Science Center, Seattle, Washington.

Dawley, EM, RD Ledgerwood, TH Blahm, CW Sims, JT Durkin, RA Kirn, AE Rankis, G. Monan, and FJ Ossiander. 1986. Migrational Characteristics, Biological Observations, and Relative Survival of Juvenile Salmonids Entering the Columbia River Estuary, 1966-1983. Report to Bonneville Power Administration, Portland, Oeregon, by National Oceanic and Atmospheric Administration (NOAA) Fisheries, Northwest Fisheries Science Center, Seattle, Washington. Contract DACW57-85-F-0623, $256 \mathrm{p}$.

Diefenderfer, HL, GE Johnson, NK Sather, JR Skalski, EM Dawley, and AM Coleman. 2010. 
Evaluation of Life History Diversity, Habitat Connectivity, and Survival Benefits Associated with Habitat Restoration Actions in the Lower Columbia River and Estuary, Annual Report 2009. PNNL19410 DRAFT, prepared by the Pacific Northwest National Laboratory, University of Washington for the U.S. Army Corps of Engineers, Portland District. June 2010, Richland, Washington.

Evans, NR, RM Thom, GD Williams, J Vavrinec, KL Sobocinski, LM Miller, AB Borde, VI Cullinan, JA Ward, CW May, and C Allen. 2006. Lower Columbia River Restoration Prioritization Framework. PNWD-3652, prepared by Battelle - Pacific Northwest Division for the Lower Columbia River Estuary Partnership, Richland, Washington.

Fresh, K, E Casillas, L Johnson, and D Bottom. 2005. Role of the Estuary in the Recovery Columbia River Basin Salmon and Steelhead: An Evaluation of Selected Factors on Salmonid Population Viability. NOAA Technical Memorandum NMFS-NWFSC-69, NOAA Fisheries, Northwest Fisheries Science Center, Seattle, Washington.

Johnson, GE and HL Diefenderfer (eds.). 2010. Evaluating Cumulative Ecosystem Response to Restoration Projects in the Lower Columbia River and Estuary, 2009. PNNL-19440, prepared by Pacific Northwest National Laboratory, Richland, Washington, and the National Marine Fisheries Service, Seattle, Washington, for the U.S. Army Corps of Engineers, Portland District, Portland, Oregon.

Johnson, GE, RM Thom, AH Whiting, GB Sutherland, T Berquam, BD Ebberts, NM Ricci, JA Southard, and JD Wilcox. 2003. An Ecosystem-Based Approach to Habitat Restoration Projects with Emphasis on Salmonids in the Columbia River Estuary. PNNL-14412, final report submitted to the Bonneville Power Administration, Portland, Oregon, by Pacific Northwest National Laboratory, Richland, Washington.

Johnson, GE, HL Diefenderfer, BD Ebberts, C Tortorici, T Yerxa, J Leary, and J Skalski. 2008. Research Monitoring and Evaluation for the Federal Columbia River Estuary Program. PNNL-17300, final report by the Pacific Northwest National Laboratory, Richland, Washington, for the Bonneville Power Administration, Portland, Oregon.

Leary, JC, JL Morace, CA Simenstad, JL Burke, TD Counihan, JR Hatten, IR Waite, KL Sobocinski, J Dietrich, F Loge, B Anulacion, J Spromberg, M Arkoosh, and L Johnson. 2005. Lower Columbia River Ecosystem Monitoring Project Annual Report for Year 2 (September 2004 to August 2005). Prepared by the Lower Columbia River Estuary Partnership for the Bonneville Power Administration, Portland, Oregon.

McMichael, GA, JA Vucelick, BJ Bellgraph, TJ Carlson, RL McComas, L Gilbreath, SG Smith, B Sandford, G Matthews, and JW Ferguson. 2007. A study to estimate salmonid survival through the Columbia River Estuary using acoustic tags, 2005 and 2006 synthesis report. PNNL-A-54927, Technical Memorandum from Pacific Northwest National Laboratory, Richland, Washington, to the U.S. Army Corps of Engineers, Portland District.

Roegner, GC, DL Bottom, AM Baptista, J Burke, SA Hinton, DA Jay, CA Simenstad, E Casillas, KK Jones. 2004. Estuarine Habitat and Juvenile Salmon: Current and Historical Linkages in the Lower Columbia River and Estuary, 2002. Report of Research by the Fish Ecology Division, Northwest 
Fisheries Science Center, National Marine Fisheries Service, National Oceanic and Atmospheric Administration to the U.S. Army Corps of Engineers, Portland, Oregon.

Roegner, GC, HL Diefenderfer, AB Borde, RM Thom, EM Dawley, AH Whiting, SA Zimmerman, and GE Johnson. 2009. Protocols for Monitoring Habitat Restoration Projects in the Lower Columbia River and Estuary. NOAA Technical Memorandum NMFS-NWFSC-97, prepared by the national Oceanic and Atmospheric Administration (NOAA) Fisheries and Pacific Northwest National Laboratory, Seattle, Washington, for the U.S. Army Corps of Engineers, Portland District, Portland, Oregon.

Sather, NK, GE Johnson, AJ Storch, DJ Teel, JR Skalski, TA Jones, EM Dawley, SA Zimmerman, AB Borde, C Mallette, and R Farr. 2009. Ecology of Juvenile Salmon in Shallow Tidal Freshwater Habitats in the Vicinity of the Sandy River Delta, Lower Columbia River, 2008. PNNL-18450, final report submitted to the Bonneville Power Administration by Pacific Northwest National Laboratory, Oregon Department of Fish and Wildlife, National Marine Fisheries Service, and University of Washington, Richland, Washington.

Simenstad, CA, JL Burke, IR Waite, TD Counihan, and JR Hatten. 2005. Lower Columbia River and Estuary Ecosystem Classification: Phase II. University of Washington and US Geological Survey report submitted to Lower Columbia River Estuary Partnership, Portland, Oregon.

Thom, RM, AB Borde, NR Evans, CW May, GE Johnson, and JA Ward. 2004. A Conceptual Model for the Lower Columbia River Estuary. PNNL-XXXXX, final report to the U. S. Army Corps of Engineers by Pacific Northwest National Laboratory, Richland, Washington.

\section{Attachment 1: RME Objectives (from Johnson et al. 2008)}

Status and Trends Monitoring: Habitat Conditions. ${ }^{1}$ Determine the status and trends of monitored indicators for estuary/ocean conditions that are ecologically significant to listed salmonids in the lower river, estuary, plume, and nearshore ocean.

- Map bathymetry and topography of the estuary as needed for RME.

- Establish a hierarchical habitat classification system based on hydrogeomorphology, ground-truth it with vegetation cover monitoring data, and map existing habitats.

- Develop an index of habitat connectivity and apply it to each of the eight reaches of the study area.

- Monitor habitat conditions periodically, including water-surface elevation, vegetation cover, plant community structure, substrate characteristics, dissolved oxygen, temperature, conductivity, and primary and secondary production at representative locations in the estuary and plume.

Status and Trends Monitoring: Juvenile Salmonid Performance. Determine the status and trends of monitored indicators for juvenile salmonid performance in the estuary and plume.

\footnotetext{
${ }^{1}$ Status and trends monitoring is defined as census or statistically designed monitoring of fish or wildlife populations and/or environmental conditions (i.e., watershed conditions) to assess the current status (at a particular time) or trend (over time).
} 
- Evaluate migration characteristics, including juvenile salmonid abundance, residence times, growth rates, diets, and prey resources at representative locations in the estuary and plume to understand habitat usage and relative ecological importance of various habitats to juvenile salmonids.

- Monitor and evaluate juvenile salmonid survival from Bonneville Dam through the estuary into the plume.

- Develop an index and monitor and evaluate the life-history diversity of juvenile salmonid populations at representative locations in the estuary.

- Monitor and evaluate temporal and spatial species composition, abundance, and foraging rates of juvenile salmonid predators at representative locations in the estuary and plume.

Action Effectiveness Research. ${ }^{2}$ Using a representative set of projects, monitor and evaluate the effects of habitat restoration actions in the estuary.

- Develop a limited number of reference sites for typical habitats, e.g., tidal swamp, marsh, island, and tributary delta, to use in action effectiveness evaluations.

- Evaluate the effects of selected individual habitat restoration actions at project sites relative to reference sites and evaluate post-restoration trajectories based on project-specific goals and objectives. ("Effectiveness Monitoring")

- Develop and implement a methodology to estimate the cumulative effects of habitat conservation and restoration projects in terms of cause-and-effect relationships between ecosystem controlling factors, structures, and processes affecting salmon habitats and performance. ("Validation Mon.")

Critical Uncertainties Research. ${ }^{3}$ Investigate critical uncertainties in the state-of-the-science in the estuary, plume, and nearshore ocean that are pivotal to understanding estuary/ocean effects on juvenile salmonid performance.

- Continue work to define the ecological importance of the tidal freshwater, estuary, plume and nearshore ocean environments to the viability and recovery of listed salmonid populations in the Columbia River basin.

- Continue work to define the causal mechanisms and migration/behavior characteristics affecting survival of juvenile salmon during their first weeks in the ocean.

- Investigate the importance of the early life history of salmon populations in tidal freshwater of the lower Columbia River.

- Investigate the effects of hatchery fish on wild (naturally produced) fish in the estuary.

${ }^{2}$ Action effectiveness research is defined as research to determine the effects of an action or suite of actions on fish survival, productivity, and/or habitat conditions. This is a manipulative experiment that statistically assesses the effect of a treatment (action) condition relative to a control or reference condition (BPA 2005).

${ }^{3}$ Uncertainties research is defined as research to resolve scientific uncertainties regarding the relationships between fish and wildlife health, population performance, habitat conditions, life history, and/or genetic conditions. Uncertainties research referenced herein requires resolution in order to successfully implement the Estuary Program. 
- Understand the wetting and drying of the floodplain habitats caused by complex hydrodynamic interactions of tides, main stem and tributary flows, and the effect of the FCRPS on river conditions.

Implementation and Compliance Monitoring. Assess whether projects are being implemented as planned and measure the amount of estuary habitat being conserved and restored annually.

- Determine whether restoration projects were carried out as planned, i.e., whether specified project criteria were met ("Implementation Monitoring").

- Total the amount of estuary habitat conserved and restored annually by habitat type.

Synthesis and Evaluation. Synthesize data from Objectives 1 through 5 and evaluate the Estuary Program within an adaptive management framework.

- Upload, compile, manage, and disseminate project-level data at the Estuary Program level.

- Synthesize the data and periodically report it to the region.

- Use the synthesized data to evaluate the Estuary Program and refine the estuary RME effort as necessary.

\section{Attachment 2: Columbia River Estuary Conceptual Ecosystem Model}

Example conceptual model for action effectiveness research from Appendix B, Johnson et al. (2008) based on Thom et al. (2004).

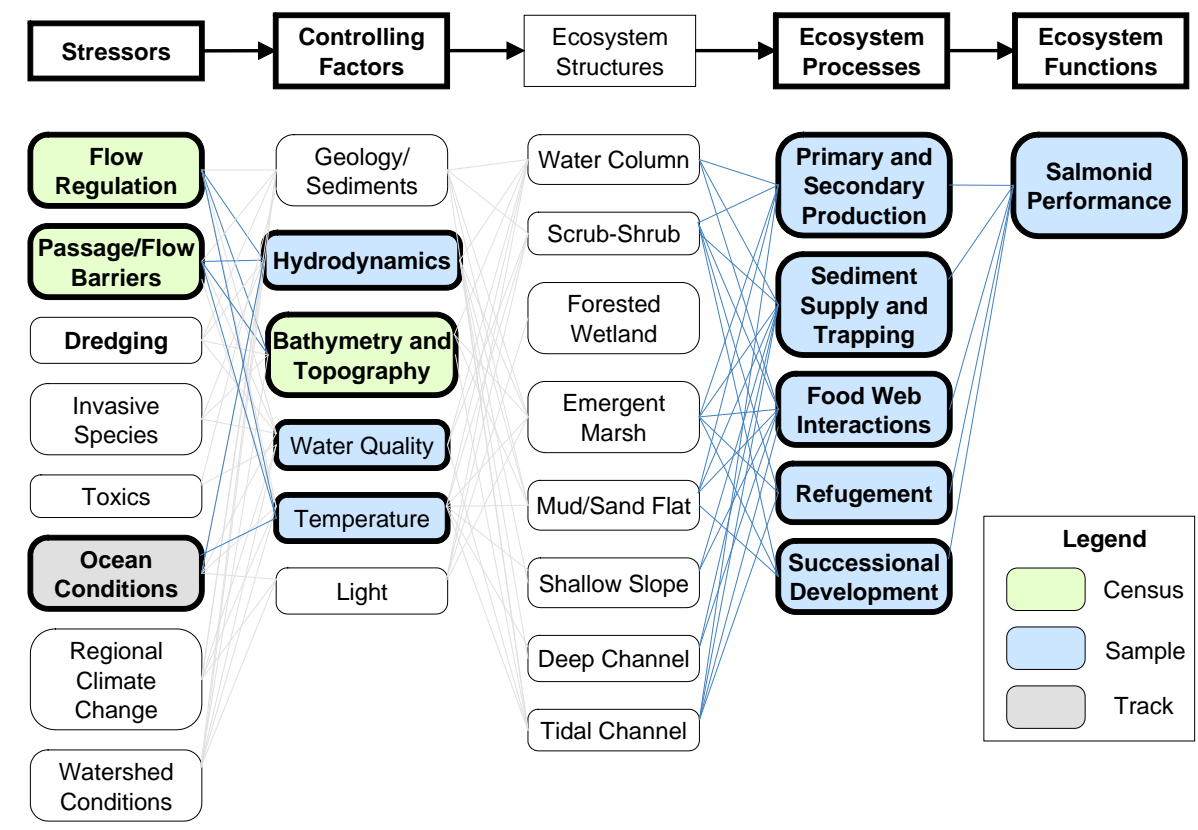

\section{Attachment 3: Estuary RME}

The following RME efforts and projects, with representative citations, provide essential support for the Estuary Program (the list is not intended to be exhaustive):

- migration characteristics (Dawley et al. 1986)

- ecosystem-based restoration framework (Johnson et al. 2003) 
- habitat linkages research project (Roegner et al. 2004)

- conceptual ecosystem model (Thom et al. 2004)

- “Salmon at River's End” (Bottom et al. 2005)

- "Role of the Estuary" (Fresh et al. 2005)

- ecosystem monitoring project (Leary et al. 2005)

- habitat classification system (Simenstad et al. 2005)

- restoration prioritization framework (Evans et al. 2006)

- $\quad$ post-FCRPS survival research project (McMichael et al. 2007)

- Estuary RME plan (Johnson et al. 2008)

- reference site network (Borde et al. 2009)

- effectiveness monitoring protocols (Roegner et al. 2009)

- tidal freshwater research project (Sather et al. 2009)

- cumulative effects research project (Johnson and Diefenderfer [eds.] 2010)

- $\quad$ salmon benefits research project (Diefenderfer et al. 2010) 



\title{
Appendix B: ERTG Template for LCRE Habitat Restoration Project Summary
}

\author{
September 22, 2010, ERTG
}

\begin{abstract}
Header:
Date

Prepared by

Sponsoring agency

Funding agency

Site

Project status or stage

Proposed Project:

Problem statement

Vision/goal

Objectives

Project action(s)

State date the summary was prepared

State name, phone number, and email address

State contact name, phone number, and email address

State contact name, phone number, and email address

State the name, location, river, and river mile

State the status or stage of the proposed project

Project elements(s)/phases by

yr

Summarize the site-specific problem(s) the proposed restoration(s) is intended to address. What are the causes of the problems?

Project size by yr

Describe the expected outcome, i.e., what the site would look like if restoration is successful.

State the project's objectives in terms of functions for salmon. For example, how will access, capacity etc. be increased or enhanced?

List the proposed restoration ${ }^{1}$ action(s) (by year), e.g., restore tidal hydrology, protect riparian zone, etc.

List the proposed restoration ${ }^{(a)}$ action(s) and phase(s) (by year) to meet the objectives.

State number of barriers to be removed, the width of the breach or reconnection, and/or the number of acres/miles ${ }^{2}$ to be restored by year.

Describe the method used to determine project size.

\begin{tabular}{ll}
\hline $\begin{array}{l}\text { Linkage to Estuary Module: } \\
\text { Estuary Module Action. }\end{array}$ Subaction(s) and Project Goal & $\begin{array}{l}\text { Identify the appropriate subaction (Attachment 1) and state the number of acres } \\
\text { or miles the project subaction will provide. Document how the value was } \\
\text { obtained. }\end{array}$ \\
\hline $\begin{array}{l}\text { Pre-Assessment: } \\
\text { Photo Point }\end{array}$ & $\begin{array}{l}\text { Whenever possible, provide summary data (values). } \\
\text { Provide a digital photograph(s) of the site; note the point and orientation of the } \\
\text { photograph, time of year, and tide/water level stage. }\end{array}$ \\
Aerial image & $\begin{array}{l}\text { Provide an aerial image from a satellite or plane. Annotate the image to convey } \\
\text { information about the project. } \\
\text { Describe the major stressors and physical controlling factors }{ }^{3} \text {. Basically } \\
\text { Condition of physical metrics }\end{array}$ \\
Condition of habitat metrics & $\begin{array}{l}\text { Describe the key results of a vegetation survey. } \\
\text { Assess or sample whether juvenile salmonids are present in the area and within } \\
\text { the site. }\end{array}$ \\
\hline $\begin{array}{l}\text { Performance Anticipated: } \\
\text { Physical change }\end{array}$ & $\begin{array}{l}\text { Describe how the action(s) will affect physical controlling factors. } \\
\text { Hescribe the expected condition of habitat. }\end{array}$ \\
Function change & $\begin{array}{l}\text { Describe the expected functional change, e.g., Juvenile salmon feeding, rearing, } \\
\text { refuge, water quality improvement, off site food web support. }\end{array}$ \\
\hline
\end{tabular}

1 As used here, the term "restoration" refers to conservation, protection, enhancement, restoration, or creation.

2 The ERTG to provide guidance on the recommended approach to determining acres/miles.

${ }^{3}$ Controlling factors are the basic physical and chemical conditions that construct and influence the structure of the ecosystem.
\end{abstract}




\begin{tabular}{|c|c|}
\hline \multicolumn{2}{|l|}{ Certainty of Success: } \\
\hline Landowner support & Describe the willingness and support of the landowner. \\
\hline Constraints or show-stoppers & Describe potential issues that could inhibit or prevent execution of the project. \\
\hline Restoration technique & $\begin{array}{l}\text { Describe the level of acceptance and maturity of the restoration technique; e.g., } \\
\text { tried and true or experimental. }\end{array}$ \\
\hline $\begin{array}{l}\text { Natural processes and self- } \\
\text { maintenance }\end{array}$ & $\begin{array}{l}\text { Explain the extent to which natural processes would be restored and how well the } \\
\text { restoration action(s) are anticipated to be maintained }\end{array}$ \\
\hline \multicolumn{2}{|l|}{ Potential Access Benefit: } \\
\hline $\begin{array}{l}\text { Distance of the project to the } \\
\text { main stem Columbia River }\end{array}$ & State distance in river miles. \\
\hline Connectedness to main stem & $\begin{array}{l}\text { Describe how well the project site will be connected to the main stem after the } \\
\text { restoration. }\end{array}$ \\
\hline Species impacted & $\begin{array}{l}\text { Describe which species, stocks, or populations are likely to benefit, based on the } \\
\text { best available data. }\end{array}$ \\
\hline \multicolumn{2}{|l|}{ Potential Capacity Benefit: } \\
\hline Habitat complexity & Describe habitat complexity, channels, large woody debris. \\
\hline Water quality & Describe water quality. \\
\hline Invasive species & Describe impacts from invasive species. \\
\hline Adjacent lands & Describe the condition of adjacent lands. \\
\hline Comments & Include comments or other pertinent information. \\
\hline
\end{tabular}

\section{Attachment 1: Actions and Subactions from the Estuary Module That Are Applicable to the ERTG Process}

CRE-1: Protect intact riparian areas in the estuary and restore riparian areas that are degraded.

CRE-1.4: Restore and maintain ecological benefits in riparian areas; this includes managing vegetation on dikes and levees to enhance ecological function and adding shoreline/instream complexity for juvenile salmonid refugia.

CRE-6: Reduce the export of sand and gravels via dredge operations by using dredged materials beneficially.

CRE-6.2: Identify and implement dredged material beneficial use demonstration projects, including the notching and scrape-down of previously disposed materials and placement of new materials for habitat enhancement and/or creation.

CRE-6.3: Dispose of dredged materials using techniques identified through the demonstration projects and region-wide planning.

CRE-8: Remove pilings and pile dikes.

CRE-8.2: Remove priority pilings and pile dikes.

CRE-9: Protect remaining high-quality off-channel habitat from degradation and restore degraded areas with high intrinsic potential for high-quality habitat

CRE-9.4: Restore degraded off-channel habitats with high intrinsic potential for increasing habitat quality. 
CRE-10: Breach or lower dikes and levees.

CRE-10.1: Breach or lower the elevation of dikes and levees; create and/or restore tidal marshes, shallow-water habitats, and tide channels.

CRE-10.2: Remove tide gates to improve the hydrology between wetlands and the channel and to provide juveniles with physical access to off-channel habitat; use a habitat connectivity index to prioritize projects.

CRE-10.3: Upgrade tide gates where (1) no other options exist, (2) upgraded structures can provide appropriate access for juveniles, and (3) ecosystem function would be improved over current conditions.

CRE-12: Reduce the effects of vessel wake stranding in the estuary.

CRE-12.2: Design and implement projects that are likely to result in the reduction of ship wake stranding events.

CRE-15: Reduce noxious weeds.

CRE-15.3: Implement projects to address infestations on public and private lands.

\section{Attachment 2: ERTG Scoring Criteria (DRAFT)}

Purpose: The process the ERTG uses to assign survival benefits for habitat restoration projects in the lower Columbia River and estuary (LCRE) involves scoring for three factors:

- certainty of success

- potential benefit from improved habitat access/opportunity

- potential benefit from improved habitat capacity/quality.

This document provides criteria for scores (1 to 5) for each factor that will help standardize the review process.

Scope: The ERTG scoring criteria apply primarily to restoration and enhancement projects. Acquisition projects are also considered provided there is a vision for restoration in future phases of the project. In addition, conservation projects that have an obvious significant contribution to functioning of the broader ecosystem may also be scored. Ocean- and stream-type fish will not be scored separately because the Estuary Module already differentiates between the two.

\section{Certainty of Success (DRAFT)}

5 - Restoring a natural process or landforms; proven restoration method; likely self-maintaining; straightforward project; minimal exotic/invasive species expected.

4 - Intermediate between 5 and 3.

3 - Partially restoring a natural process or landforms; proven restoration method; potentially selfmaintaining; more project complexity and uncertainties to benefit fish; exotic/invasive species expected.

2 - Intermediate between 3 and 1. 
1 - Unlikely to restore natural processes and landforms; unproven or risky restoration method; will likely require intervention to maintain; long-term maintenance required; some risk of detrimental effects; excessive project complexity and uncertainties; exotic/invasive species expected.

\section{Potential Benefit from Improved Habitat Access/Opportunity (DRAFT)}

5 - High connectivity of site and access for most species and populations coming down river at most water level stages; located in a main stem area or a priority (TBD) reach; simple access to project within site; converts a sites condition from one of no or limited access to one of fully restored access.

4 - Intermediate between 5 and 3; increases site access significantly.

3 - Partial connectivity, only accessible to specific life history types or one species; located in a main stem area, lower end of tributary or a priority (TBD) reach; modestly increases site access.

2 - Intermediate between 3 and 1; unlikely to increase site accessibility, or barely increases site access.

1 - Minimal to no improvement in connectivity; poorly accessible to specific life-history types or species; located in areas far from main stem or lower ends of tributaries; clearly does not increase site accessibility.

\section{Potential Benefit from Improved Habitat Capacity/Quality (C/Q) (DRAFT)}

5 - Maximum natural habitat ecological complexity; well-developed natural disturbance regime and ecosystem functions; extensive channel and edge network and large wood; much prey resource production and export; no invasive species or nuisance predators; water quality/temperature excellent; increases site $\mathrm{C} / \mathrm{Q}$ from near zero to near maximum site potential; relatively large site (> $100 \mathrm{ac}$ ).

4 - Intermediate between 5 and 3; increases site C/Q significantly; relatively large site (30-100 ac)

3 - Moderate habitat complexity or heterogeneity; ecosystem functioning could be improved, but not at ideal level; some channel and edge network and large wood; moderate prey resource production; moderate potential invasive species or predators; water quality/temperature moderate; modestly increases site C/Q, modest size of site $(<30 \mathrm{ac})$.

2 - Intermediate between 3 and 1; unlikely to increase site C/Q, or barely increases site C/Q.

1 - Simple, small habitat with little ecological complexity; expected ecosystem functioning minimal; moderate poor prey resource production; moderate potential invasive species or predators; water quality/temperature poor; clearly does not increase C/Q. 


\section{Distribution}

No. of PDF

Copies

Catherine Corbett

Lower Columbia River Estuary

Partnership

811 SW Naito Parkway, Suite 120

Portland, Oregon 97204

Russell Scranton

Bonneville Power Administration

PO Box 3621

Portland, Oregon 97208

Blaine Ebberts

U.S. Army Corps of Engineers

333 SW First Avenue

Portland, Oregon 97204

Jim Geiselman

Bonneville Power Administration

PO Box 3621

Portland, Oregon 97208

Chris Hathaway

Lower Columbia River Estuary

Partnership

811 SW Naito Parkway, Suite 120

Portland, Oregon 97204
No. of PDF

Copies

Krista Jones

Lower Columbia River Estuary

Partnership

811 SW Naito Parkway, Suite 120

Portland, Oregon 97204

Cindy Studebaker

U.S. Army Corps of Engineers

333 SW First Avenue

Portland, Oregon 97204

Cathy Tortorici

NOAA Fisheries

1201 NE Lloyd Blvd.

Portland, Oregon 97232

Tracey Yerxa

Bonneville Power Administration

PO Box 3621

Portland, Oregon 97208

2 Local Distribution

Pacific Northwest National Laboratory

Gary Johnson

BPO

Heida Diefenderfer

SEQUIM 


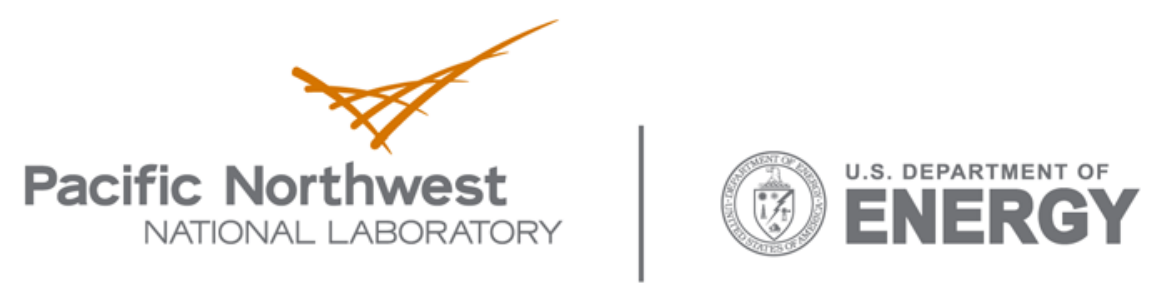

902 Battelle Boulevard

P.O. Box 999

Richland, WA 99352

1-888-375-PNNL (7665)

www.pnl.gov 